\title{
Isolation of obligately alkaliphilic magnetotactic bacteria from extremely alkaline
}

environments

Christopher T. Lefèvre, ${ }^{1}$ Richard B. Frankel, ${ }^{2}$ Mihály Pósfai, ${ }^{3}$ Tanya Prozorov ${ }^{4}$ and

Dennis A. Bazylinski ${ }^{1 *}$

${ }^{1}$ School of Life Sciences, University of Nevada at Las Vegas, Las Vegas, NV 89154-4004, USA.

${ }^{2}$ Department of Physics, California Polytechnic State University, San Luis Obispo, CA 93407, USA.

${ }^{3}$ Department of Earth and Environmental Sciences, University of Pannonia, H-8200 Veszprém, Hungary.

${ }^{4}$ Ames Laboratory, U.S. Department of Energy, Ames, IA 50011, USA.

\section{Summary}

Large numbers of magnetotactic bacteria were discovered in mud and water samples collected from a number of highly alkaline aquatic environments with $\mathrm{pH}$ values of -9.5 . These bacteria were helical in morphology and biomineralized chains of bullet-shaped crystals of magnetite and were present in all the highly alkaline sites sampled. Three strains from different sites were isolated and cultured and grew optimally at $\mathrm{pH}$ 9.0-9.5 but not at 8.0 and below, demonstrating that these organisms truly require highly alkaline conditions and are not simply surviving/growing in neutral $\mathrm{pH}$ micro-niches in their natural habitats. All strains grew anaerobically through the reduction of sulfate as a terminal electron acceptor and phylogenetic analysis, based on 16S rRNA gene sequences, as well as some physiological features, showed that they could represent strains of Desulfonatronum thiodismutans, a known alkaliphilic bacterium that does not biomineralize magnetosomes. Our results show that some magnetotactic bacteria can be considered extremophilic and greatly extend the known ecology of magnetotactic bacteria and the conditions under which they can biomineralize magnetite. Moreover, our results show that this type of magnetotactic bacterium is common in highly alkaline environments. Our findings also greatly 
influence the interpretation of the presence of nanometer-sized magnetite crystals, so-called magnetofossils, in highly alkaline environments.

\section{Introduction}

Magnetotactic bacteria (MTB) are a heterogeneous group of motile, mostly aquatic prokaryotes that display magnetotaxis, a phenomenon in which the microorganism's direction of motility is influenced by the Earth’s geomagnetic and applied local magnetic fields (Blakemore, 1975). This is due to the ability of MTB to biomineralize magnetosomes that are intracellular, membrane-bounded magnetic crystals of the minerals magnetite (Fe3O4) and/or greigite (Fe3S4) (Bazylinski and Frankel, 2004). Known cultured and uncultured MTB are phylogenetically associated with the Alpha, Gamma and Deltaproteobacteria classes of the Proteobacteria and the Nitrospirae phyla (Bazylinski and Frankel, 2004; Amann etal., 2006; C.T. Lefèvre, N. Viloria, M. Pósfai, R.B. Frankel and D.A. Bazylinski, submitted). MTB are generally thought to be ubiquitous in aquatic environments (Bazylinski and Frankel, 2004) as they are cosmopolitan in distribution and have been found in every continent (Bazylinski and Schübbe, 2007). However, they have never been viewed as 'extremophiles'; that is, they have never been reported from habitats considered extreme with regard to $\mathrm{pH}$ and temperature, although a moderately thermophilic species from hot springs was recently described (Lefèvre et al., 2010).

Naturally occurring alkaline environments are relatively uncommon on Earth. Soda lakes represent the most stable high-pH environments on this planet and they are known to be present on six continents (Jones et al., 1998). Despite their apparently hostile conditions, these lakes are among the most productive aquatic environments in the world (Jones et al., 1994; 1998). The main geochemical conditions of their formation include leaching of rock material, usually rich in $\mathrm{Na}^{+}$but

low in $\mathrm{Ca}^{2+}$ and $\mathrm{Mg}^{2+}$, by $\mathrm{CO} 2$-saturated waters, generally in areas with a dry and warm climate 
where evaporative concentration of the brines in natural depressions is easily facilitated (Jones et al., 1977). Under such conditions, $\mathrm{Na}^{+}$becomes dominant among the cations and $\mathrm{HCO}^{-} / \mathrm{CO}^{2-}, \mathrm{Cl}^{-}$ and $\mathrm{SO}^{2-}$ are the dominant anions in solution. The presence of sodium carbonate in variable combinations with sodium chloride and sodium sulfate creates a unique, buffered halo-alkaline habitat that is stable enough for the selective development of populations of obligately halo- and alkaliphilic microorganisms (Krulwich, 2006). The ancient nature, geochemistry and microbiology of soda lakes have been studied to provide insight into the origin of life on Earth and to demonstrate the potential for life on other planets, such as Mars (Kempe and Degens, 1985; Kempe and Kazmierczak, 1997; Bibring et al., 2006).

Although various definitions of 'alkaliphilic' have been used in the literature, the only common standard is that the organism's optimal $\mathrm{pH}$ for growth must be at least two $\mathrm{pH}$ units above neutrality (Kroll, 1990). Alkaliphilic bacteria are a very diverse group of prokaryotes that must cope with a number of problems associated with surviving and growing at high $\mathrm{pH}$, most notably the problem of maintaining an intracellular $\mathrm{pH}$ that is close to neutral (Krulwich, 2006). Among the numerous types of prokaryotes that thrive in highly alkaline environments, sulfate-reducing bacteria have been studied in detail (Zhilina et al., 1997).

In this study, we examined a number of highly alkaline sites in California, USA for the presence of MTB. Here we report the first isolation and axenic culture of obligately alkaliphilic MTB and discuss their significance to microbiology and geology.

\section{Results}

\section{MTB in highly alkaline environments}

Mud and water samples collected from three highly alkaline sites with $\mathrm{pH}$ - 9.5-9.8 including:

(i) the hypersaline (salinity 68-70 ppt) Mono Lake, California; (ii) a brackish ( -3 ppt) spring 
and associated pool at Death Valley Junction (Armagosa) near the border of Nevada and California and (iii) the saline (- $27 \mathrm{ppt}$ ) Soda Spring at the Desert Studies Center located on Zzyzx Road, California, contained a significant population $\left(>10^{3}\right.$ cells $\mathrm{ml}^{-1}$ ) of MTB of a single, morphological type. Cells were helical, possessed a single polar flagellum and contained one or two parallel chains of bullet-shaped magnetite-containing magnetosomes (Fig. 1).

\section{[Insert Figure 1]}

The 16S rRNA genes of magnetically enriched and purified, uncultured cells from Mono Lake and the brackish pool at Death Valley Junction were amplified with PCR using Bacteria- and Archaea-specific primers. Two very similar sequences from each site (>_ $98.2 \%$ identity between each pair of the four sequences) were obtained using the Bacteria-specific primers. No PCR product was obtained with Archaea-specific primers. Phylogenetic analysis showed these organisms to be closely related (16S rRNA gene sequence identities >_ 98.9\%) to the nonmagnetotactic, alkaliphilic, sulfate-reducing deltaproteobacterium, Desulfonatronum thiodismutans isolated from Mono Lake (Pikuta et al., 2003).

[Insert Figure 2]

Isolation, phylogeny and growth of alkaliphilic MTB

Magnetically purified cells from all three sites were used as inocula in a growth medium modified from Pikuta and colleagues (2003) to reflect the salinities of the sampling sites, for the cultivation of anaerobic, alkaliphilic, sulfate-reducing bacteria. Cells with the same morphology as those found in the mud and water samples grew in this growth media but did not exhibit observable magneto-taxis using the hanging drop technique (Schüler, 2002). Strains from the three sites were isolated by dilution to extinction and designated ML-1 (Mono Lake), ZZ-1 (Zzyzx Road) and AV-1 (Armagosa Valley). 16S rRNA gene sequences of the isolated strains 
were identical or very similar ( $>$ $98.6 \%$ sequence identity) to those of magnetically purified uncultured cells from the same environments confirming the authenticity of the uncultured cell sequences. All isolated strains were phylogenetically closely related to D. thiodismutans (16S rRNA gene sequence identity >_98.8\%) and could be considered as new strains of this species (Fig. 2) depending on the minimal sequence identity used for the species taxon (Clarridge, 2004; Gevers et al., 2005; Doolittle and Papke, 2006).

Cells in the axenic cultures did not initially display magnetotaxis. The reason for this was initially unclear but a good possibility was that cells were iron-limited with regard to magnetosome biomineralization resulting in weak or no magnetism, because iron in the growth medium quickly precipitated as black iron sulfides once cells started to reduce sulfate to sulfide. Thus, to obtain a greater magnetotactic response, the iron concentration was increased from 20 to $200 \mu \mathrm{M}$ and the headspace of the cultures purged every other day with oxygen-free argon gas to decrease the concentration of hydrogen sulfide in the cultures. When this was done, cells became magnetotactic and contained chains of and dispersed bullet-shaped, magnetite-containing magnetosomes (Fig. 1B and C).

Like typical dissimilatory sulfate-reducing bacteria including $D$. thiodismutans, growth of strains ML-1, ZZ-1 and AV-1 was dependent on sulfate and cells produced sulfide from sulfate during growth (Fig. 3). Additional proof of sulfate reduction included the presence of important genes for sulfate reduction including dissimilatory sulfite reductase ( $d s r A B)$ and adenosine-5'-phosphate reductase (aprA) in all three isolates. Other more specific growth characteristics were similar to $D$. thiodismutans (Pikuta etal., 2003). All strains used formate and hydrogen as electron donors and could grow autotrophically with hydrogen as the electron donor with bicarbonate as the sole carbon source. The addition of acetate or yeast extract stimulated growth with hydrogen or 
formate, but cells could not grow with these compounds in the absence of hydrogen and formate suggesting that the strains grow mixotrophically. Strains ML-1, ZZ-1 and AV-1 can be considered obligately alkaliphilic given that their optimal growth occurs at pH 9.0-9.5, and they did not grow at $\mathrm{pH}<8.0$. Growth was slow at $\mathrm{pH}$ values between 8.0 and 9.0.

[Insert Figure 3]

Neither magnetotaxis nor magnetite magnetosome synthesis has ever been described in Desulfonatronum species. The type strain of D. thiodismutans (ATCC strain No. BAA-395; DSMZ strain No. 14708), the closest phylogenetic relative to the three alkaliphilic strains of MTB, was grown on our modified growth medium in an effort to test whether cells could become magnetotactic. Cells grew well in the medium when the salinity was specifically adjusted for the strain, but never became magnetotactic nor did they biomineralize magnetosomes.

\section{Discussion}

Highly alkaline springs and ponds, relatively common in the Southwestern USA, appear to not have been thoroughly examined for the presence of MTB or for the presence of magnetosome magnetofossils and, despite the fact that MTB are considered ubiquitous in aquatic habitats and cosmopolitan in distribution, MTB have never been considered extremophilic with regard to temperature and $\mathrm{pH}$. A moderately thermophilic, uncultured MTB was recently described but even this organism would not be considered hyperthermophilic or obligately thermophilic given the temperature range of the hot springs where it was found $\left(32-62^{\circ} \mathrm{C}\right)$ (Lefèvre et al., 2010). In this report, we describe the presence and isolation of obligately extremophilic, alkaliphilic MTB from highly alkaline environments. Three similar strains from different sites were isolated and cultured and grew optimally at $\mathrm{pH} 9.0-9.5$ but not at 8.0 and below, demonstrating that these 
MTB truly require highly alkaline conditions and are not simply surviving/growing in neutral $\mathrm{pH}$ micro-niches in their natural habitats.

Alkaliphilic bacteria have a number of physiological problems to deal with living in such a harsh environment including keeping their intracellular $\mathrm{pH}$ around neutral in an extracellular $\mathrm{pH}$ of $>9.0$ and they have developed interesting ways to overcome these problems (Krulwich, 2006). In the case of alkaliphilic MTB, how these bacteria synthesize large numbers of magnetosomes in natural environments is particularly interesting in that at high alkaline $\mathrm{pH}$, iron is extremely insoluble (Jimenez-Lopez etal., 2010) and thus MTB must possess highly efficient mechanisms of iron uptake under these conditions. The fact that these microorganisms exist in the reducing anoxic zone in these environments where iron is likely to be in the more soluble ferrous form, rather than the oxic zone of their habitat probably obviates part of this problem. Another related problem found to occur in culture that seems to inhibit magnetite magnetosome synthesis in the alkaliphilic MTB, is that sulfide produced from sulfate reduction reacts relatively quickly with iron in the growth medium resulting in the precipitation of iron sulfides. When the iron concentration in the growth medium was increased and hydrogen sulfide removed by sparging the cultures with O2-free argon gas, magnetite magnetosome biomineralization resumed. This does not seem to occur in natural environments as cells appear to produce a significantly greater number of magnetosomes per cell (data not shown). In natural environments, it is possible that sulfide diffuses away from cells, and never reaches the concentrations in cultures, resulting in a larger number of magnetosomes per cell. It is also possible that cells might utilize an alternative to sulfate as terminal electron acceptor in natural environments where sulfide formation is not involved. For example, the magnetotactic Desulfovibrio magneticus strain RS-1 (Sakaguchi et al., 1993) is able to grow with fumarate as an alternate electron acceptor to sulfate (Sakaguchi et al., 2002). Because MTB accumulate large 
amounts of intracellular iron, up to 2.2\% of their dry weight (Heyen and Schüler, 2003), and because there are few studies on how bacteria growing at extreme alkaline $\mathrm{pH}$ acquire iron (McMillan et al., 2010), it would be interesting to study the mechanisms of iron uptake in these new strains of obligately alkaliphilic MTB.

Based on the 16S rRNA gene sequences of the alkaliphilic MTB described here, all three isolates could be considered strains of $D$. thiodismutans (Pikuta etal., 2003), depending on the percentage of sequence identity used to determine species (Clarridge, 2004; Gevers et al., 2005; Doolittle and Papke, 2006). Also in support of this idea, the physiology of the new alkaliphilic strains of MTB was more similar to that of $D$. thiodismutans than to the related species Desulfonatronum lacustre, in that the strains grew anaerobically with sulfate as the terminal electron and autotrophically with hydrogen as the electron donor. D. lacustre is known to have a lithoheterotrophic type of metabolism (Pikuta et al., 1998), whereas D. thiodismutans can grow lithoautotrophically using CO2 as the only carbon source (Pikuta et al., 2003). A final, definitive determination of whether the new alkaliphilic strains of MTB represent new species or strains of existing species of Desulfonatronum will require additional testing such as DNA: DNA hybridization studies between the strains.

Neither magnetotaxis nor magnetite magnetosome synthesis has ever been described in the genus Desulfonatronum and attempts to get the type strain of $D$. thiodismutans to biomineralize magnetosomes by growing it in our modified medium were unsuccessful. An interesting question is whether the type strain of D. thiodismutans, isolated from Mono Lake where one of our MTB was found, was magnetotactic when originally isolated. This is possible as many cultivated MTB are known to lose this trait relatively easily in culture (Schübbe et al., 2003; Schüler, 2008), from the loss of a magnetosome genomic island in which the genes for magnetite biomineralization are 
located (Schübbe et al., 2003; Schüler, 2008). A larger, perhaps more interesting and important question is whether and how many magnetotactic prokaryotic organisms have been isolated and deposited in culture collections but have never been recognized as magnetotactic for various reasons. This may be most applicable to the sulfate-reducing bacteria, as another magnetotactic sulfate-reducing bacterium, D. magneticus strain RS-1, also appears to have difficulty in biomineralizing magnetite magnetosomes in culture and only displays a weak magnetotactic response (Pósfai et al., 2006). Magnetite biomineralization in magnetotactic sulfate-reducing bacteria seems to require a higher concentration of iron than that normally used for other, nonsulfate-reducing, MTB (e.g. Magnetospirillum species) ( 20 mM) (e.g. Blakemore et al., 1979) and a low sulfide concentration to prevent the scavenging iron from the growth medium. Thus, the systematic use of high concentrations of sulfide (e.g. $0.4 \mathrm{~g} \mathrm{l}^{-1} \mathrm{Na} 2 \mathrm{~S} \cdot 9 \mathrm{H} 2 \mathrm{O}$; e.g. Pikuta et al., 2003), as the typical reducing agent in growth medium for sulfate-reducing bacteria (Postgate, 1963), might preclude the formation of magnetite in magnetotactic sulfate reducers.

The discovery of MTB in highly alkaline environments clearly extends the ecological limits and perhaps the geographical distribution of the MTB and demonstrates that some MTB species can be considered extremophilic. In addition, our results suggest that sulfate-reducing MTB are common in highly alkaline environments. Because MTB have never been thought to inhabit extreme environments, highly alkaline habitats have apparently not been searched for magnetofossils, specific types of magnetite crystals representing putative remains of MTB in terrestrial and extraterrestrial materials (Jimenez-Lopez et al., 2010). The discovery of significant carbonate deposits and smectite clays on the surface of Mars are thought to be indicative of a period of highly alkaline conditions on the planet in the past (Kempe and Degens, 1985). Chemical analyses of soil samples of Mars performed by the 2007 Phoenix Mars Scout Lander showed that their pH was 7.7 
\pm 0.5 (Hecht et al., 2009; Kounaves et al., 2010), although this does not exclude the possibility of highly alkaline soils in other, perhaps more confined areas, such as occur on Earth. Moreover, equilibrium modelling based on measured $\mathrm{Ca}^{2+}$ and $\mathrm{Mg}^{2+}$ concentrations were consistent with carbonate equilibrium for a saturated solution (Hecht et al., 2009; Kounaves et al., 2010) and thus carbonate buffering appears to be as significant in some Martian soils as it is in some of the alkaline habitats we studied (e.g. Mono Lake). Mono Lake has been used by researchers at a number of institutions, including the National Aeronautics and Space Administration (NASA), as a model for extreme environments that might be comparable with those on the planet Mars (Kempe and Kazmierczak, 1997). It would be interesting to determine whether bullet-shaped magnetite crystals like those in strains ML-1, AV-1 and ZZ-1 are incorporated and preserved as magnetofossils in carbonate minerals, such as the unusual carbonate structures known as tufas in Mono Lake, as they are in sedimentary carbonates in marine environments (McNeill et al., 1988; Sakai and Jige, 2007) and in carbonates in the Martian meteorite ALH84001 (Thomas-Keprta et al., 2002).

\section{Experimental procedures}

\section{Study sites and sample collection}

Water and sediment samples were taken from three highly alkaline environments in California, USA. Mono Lake is a well-characterized lake located on the arid eastern side of the Sierra Nevada Mountains in California. The waters of this endorheic, monomictic basin exhibit high alkalinity (pH 9.2 to 10) and salinity (75-90 $\mathrm{g} \mathrm{l}^{-1}$ ) (Oremland et al., 2000). The high sodium and carbonate concentrations present at this site are derived from weathering of the surrounding volcanic rocks and hydrothermal inflow (Oremland et al., 2000; Kulp et al., 2007). Sulfate reduction accounts for $41 \%$ of the mineralization of annual primary production in Mono Lake (Hoeft et al., 2004). 
Two locations at Mono Lake were sampled [(i) $38.0249^{\circ} \mathrm{N}, 119.0802^{\circ} \mathrm{W}$ and (ii) $37.9935^{\circ} \mathrm{N}$, $\left.119.1426^{\circ} \mathrm{W}\right]$. The second site was Soda Spring, which is a small alkaline spring situated at the Desert Studies Center located at the end of Zzyzx Road south of Interstate 15 (35.1430 $\mathrm{N}$, $\left.116.1054^{\circ} \mathrm{W}\right)$. The third site sampled is an unnamed small pond in Armagosa Valley situated at Death Valley Junction (Armagosa) near the border of Nevada and California $\left(36.3016^{\circ} \mathrm{N}\right.$, $\left.116.4128^{\circ} \mathrm{W}\right)$. This alkaline pond likely results from underground water flowing through the alkaline desert uplands of Ash Meadows National Wildlife Refuge (Weimeyer et al., 2005; AlQudah et al., 2011) situated close to Armagosa.

Sampling was done onshore by filling $1 \mathrm{l}$ glass bottles to about $0.2-0.3$ of their volume with sediment, the remainder of the bottles filled to their capacity with water that overlaid the sediment. Air bubbles were excluded. Once in the laboratory, samples were stored in the bench at room temperature $\left(\sim 25^{\circ} \mathrm{C}\right)$ in the dark or under dim light. Salinities of the samples were determined with a hand-held Palm Abbe PA203 digital refractometer (MISCO Refractometer, Cleveland, OH, USA).

\section{Light and electron microscopy}

The presence and behaviour of microorganisms was observed using light microscopy with a Zeiss (Carl Zeiss MicroImaging, Thornwood, NY, USA) AxioImager M1 microscope equipped with phase-contrast and differential interference contrast capabilities. The hanging-drop technique (Schüler, 2002) was used routinely in the determination of the presence of MTB. The presence of magnetosomes and the composition of magnetosome crystals were determined using a Tecnai (FEI Company, Hillsboro, OR, USA) Model G2 F30 Super-Twin and a Philips (FEI Company, Hillsboro, OR) CM20 transmission electron microscope equipped with an attached Noran Voyager (Noran Instruments, Middleton, WI, USA) energy-dispersive X-ray detector. High- 
resolution lattice images of the magnetosomes were obtained using a JEOL 3010 transmission electron microscope (JEOL USA, Peabody MA, USA).

Growth conditions, medium composition and isolation of magnetotactic strains

Cells of MTB from samples were magnetically enriched by placing the south pole of a magnetic stirring bar next to the sample bottles about $1 \mathrm{~cm}$ above the sediment-water interface for approximately 30 min, where they would accumulate and could be removed easily with a Pasteur pipette. These MTB were then magnetically purified using the magnetic 'capillary racetrack' technique (Wolfe et al., 1987) and used as inocula into a growth medium modified from Pikuta and colleagues (2003). Modifications were that the basal medium contained (per litre): $5 \mathrm{ml}$ modified Wolfe’s mineral elixir (Wolin et al., 1963; Bazylinski et al., 2000); $0.2 \mathrm{ml}$ 1\% aqueous resazurin; 0.3 g NH4Cl; 0.1 g MgCl2•6H2O; 0.2 g KCl; 3.0 g Na2SO4; 0.2 g yeast extract; 4.0 g sodium formate; 30.0, 12.0 and $0 \mathrm{~g} \mathrm{NaCl}$ for ML-1, ZZ-1 and AV-1, respectively, and 24.0, 9.6 and $1 \mathrm{~g}$ NaHCO3 for ML-1, ZZ-1 and AV-1 respectively. The medium was then bubbled with O2free $\mathrm{N} 2$ for $25 \mathrm{~min}$ at approximately $100 \mathrm{ml} \mathrm{min}{ }^{-1}$ and autoclaved. After autoclaving, $0.5 \mathrm{ml}$ of an anaerobic stock solution of vitamins (Frankel et al., 1997); $20 \mathrm{ml}$ of $10 \mathrm{mM} \mathrm{FeSO4•7H2O} \mathrm{(in} 0.02$ $\mathrm{M} \mathrm{HCl);} 0.4 \mathrm{~g}$ of freshly made neutralized filtered sterilized cysteine $\bullet \mathrm{HCl}$ and 3.5, 1.4 and $1 \mathrm{~g}$ of freshly made filtered sterilized Na2CO3 for strains ML-1, ZZ-1 and AV-1, respectively, were added to the media. The final $\mathrm{pH}$ was $\sim 9.5$. Cultures were incubated at $25^{\circ} \mathrm{C}$. Axenic cultures of strains ML-1, ZZ-1 and AV-1 were obtained by dilution to extinction, a process that was repeated three times in succession.

Determination of gene sequences and phylogenetic analysis

16S rRNA genes of magnetically enriched, magnetically purified MTB from environmental samples and axenic cultures of MTB were amplified using Bacteria-specific primers 27F 5'- 
AGAGTTTGATCMTGGCTCAG-3' and 1492R 5'-TAC GGHTACCTTGTTACGACTT-3' (Lane, 1991) or Archaeaspecific primers 8aF 5'-TCYGGTTGATCCTGCC-3' (Burggraf etal., 1991) and 1512uR 5'-ACGGHTACCTTGTTACGA CTT-3' (Lane, 1991) and whole cell polymerase chain reaction (PCR). PCR products were cloned into pGEM-T Easy Vector (Promega Corporation, Madison, WI, USA) and sequenced (Functional Biosciences, Madison, WI, USA). The genes for sulfate reduction including dissimilatory sulfite reductase ( $d s r A B)$ and adenosine-5'-phosphate reductase (aprA) were also amplified with PCR using primers specific for these genes (Wagner et al., 1998; Meyer and Kuever, 2007).

Alignment of 16S rRNA genes was performed using CLUSTAL W multiple alignment accessory application in the BioEdit sequence alignment editor (Hall, 1999). Phylogenetic trees were constructed using MEGA version 4.1 (Tamura et al., 2007) applying the neighbour-joining method (Saitou and Nei, 1987). Bootstrap values were calculated with 1000 replicates.

\section{Cell growth and sulfate reduction}

Bacterial growth was measured by direct cell count under a phase-contrast light microscopy with a Petroff-Hausser bacterial counting chamber. Sulfide concentrations in growth medium were determined using the technique of CordRuwisch (1985). Growth curves were constructed using triplicate cultures of each strain.

\section{Nucleotide sequence accession numbers}

16S rRNA gene sequences of the strains ML-1, ZZ-1 and AV-1 carry the following GenBank accession numbers: HQ595725, HQ595726 and HQ595727 respectively. Sequences for the dissimilatory sulfite reductase ( $d s r A B)$ and dissimilatory adenosine-5'-phosphate reductase (aprA) genes for the axenic cultures carry the following GenBank accession numbers. dsrAB: ML-1, 
HQ659545; ZZ-1, HQ659546, and AV-1, HQ659547. aprA: ML-1, HQ659548; ZZ-1, HQ659549; and AV-1, HQ659550.

\section{Acknowledgements}

We thank F. Mahlaoui and F. Abreu for help with sampling, E.V. Pikuta for providing us with a culture of $D$. thiodismutans strain $\mathrm{MLF}^{\mathrm{T}}$ and R.V. Morris for helpful discussions. We are also grateful to the helpful staff of the Mono Lake Tufa State Natural Reserve. Samples were collected under Permit to Conduct Biological, Geological, or Soil Investigations/ Collections number 2010_ 21 issued by the State of California Department of Parks and Recreation. This work was supported by U.S. National Science Foundation (NSF) Grant EAR-0715492. Part of the transmission electron microscope analysis, was carried out at the Ames Laboratory, and was supported by the U.S. Department of Energy’s Basic Energy Sciences program under contract No. DE-AC02$07 \mathrm{CH} 11358$.

\section{References}

Al-Qudah, O., Woocay, A., and Walton, J. (2011) Identification of probable groundwater paths in the Amargosa Desert vicinity. Appl Geochem 26: 565-574.

Amann, R., Peplies, J., and Schüler, D. (2006) Diversity and taxonomy of magnetotactic bacteria. In Magnetoreception and Magnetosomes in Bacteria. Vol. 3. Schüler, D. (ed.). Berlin, Germany: Springer, pp. 25-36.

Bazylinski, D.A., and Frankel, R.B. (2004) Magnetosome formation in prokaryotes. Nat Rev Microbiol 2: 217-230.

Bazylinski, D.A., and Schübbe, S. (2007) Controlled biomineralization by and applications of magnetotactic bacteria. Adv Appl Microbiol 62: 21-62. 
Bazylinski, D.A., Dean, A.J., Schüler, D., Phillips, E.J., and Lovley, D.R. (2000) N2-dependent growth and nitrogenase activity in the metal-metabolizing bacteria, Geobacter and Magnetospirillum species. Environ Microbiol 2: 266-273.

Bibring, J.-P., Langevin, Y., Mustard, J.F., Poulet, F., Arvid-son, R., Gendrin, A., etal., the OMEGA Team (2006) Global mineralogical and aqueous Mars history derived from OMEGA/Mars Express data. Science 312: 400-404.

Blakemore, R.P. (1975) Magnetotactic bacteria. Science 190: 377-379.

Blakemore, R.P., Maratea, D., and Wolfe, R.S. (1979) Isolation and pure culture of a freshwater magnetic spirillum in chemically defined medium. J Bacteriol 140: 720-729.

Burggraf, S., Stetter, K.O., Rouviere, P., and Woese, C.R. (1991) Methanopyrus kandleri: an archaeal methanogen unrelated to all other known methanogens. Syst Appl Microbiol 14: 346351.

Clarridge, J.E., III (2004) Impact of 16S rRNA gene sequence analysis for identification of bacteria on clinical microbiology and infectious disease. Clin Microbiol Rev 17: 840-862.

Cord-Ruwisch, R. (1985) A quick method for the determination of dissolved and precipitated sulfides in cultures of sulfate-reducing bacteria. J Microbiol Methods 4: 33-36.

Doolittle, W.F., and Papke, R.T. (2006) Genomics and the bacterial species problem. Genome Biol7: 116.

Frankel, R.B., Bazylinski, D.A., Johnson, M.S., and Taylor, B.L. (1997) Magneto-aerotaxis in marine coccoid bacteria. Biophys J 73: 994-1000.

Gevers, D., Cohan, F.M., Lawrence, J.G., Sprat, B.G., Coeyne, T., Feil, E.J., et al. (2005) Opinion: re-evaluating prokaryotic species. Nat Rev Microbiol 3: 733-739. 
Hall, T.A. (1999) BioEdit: a user-friendly biological sequence alignment editor and analysis program for Windows 95/98/ NY. Nucleic Acids Symp Ser 41: 95-98.

Hecht, M.H., Kounaves, S.P., Quinn, R.C., West, S.J., Young, S.M.M., Ming, D.W., et al. (2009) Detection of perchlorate and the soluble chemistry of martian soil at the Phoenix Lander site. Science 325: 64-67.

Heyen, U., and Schüler, D. (2003) Growth and magnetosome formation by microaerophilic Magnetospirillum strains in an oxygen-controlled fermentor. Appl Microbiol Biotechnol61: 536544.

Hoeft, S.E., Kulp, T.R., Stolz, J.F., Hollibaugh, J.T., and Oremland, R.S. (2004) Dissimilatory arsenate reduction with sulfide as electron donor: experiments with mono lake water and isolation of strain MLMS-1, a chemoautotrophic arsenate respirer. Appl Environ Microbiol 70: 2741-2747.

Jimenez-Lopez, C., Romanek, C.S., and Bazylinski, D.A. (2010) Magnetite as a prokaryotic biomarker: a review. J Geophys Res-Biogeo 115: G00G03.

Jones, B.E., Grant, W.D., Collins, N.C., and Mwatha, W.E. (1994) Alkaliphiles: diversity and identification. In Bacterial Diversity and Systematics. Priest, F.G., RamosCormenzana, A., and Tindall, B.J. (eds). New York: Plenum Press, pp. 195-230.

Jones, B.E., Grant, W.D., Duckworth, A.W., and Owenson, G.G. (1998) Microbial diversity of soda lakes. Extremophiles 2: 191-200.

Jones, B.F., Eugster, H.P., and Rettig, S.L. (1977) Hydrochemistry of the Lake Magadi basin, Kenya. Geochim Cosmochim Acta 41: 53-72.

Kempe, S., and Degens, E.T. (1985) An early soda ocean? Chem Geol53: 95-108. 
Kempe, S., and Kazmierczak, J. (1997) A terrestrial model for an alkaline Martian hydrosphere. Planet Space Sci 45: 1493-1495.

Kounaves, S.P., Hecht, M.H., Kapit, J., Gospodinova, K., DeFlores, L., Quinn, R.C., etal. (2010) Wet chemistry experiments on the 2007 Phoenix Mars Scout Lander mission: data analysis and results. J Geophys Res 115: E00E10.

Kroll, R.G. (1990) Alkalophiles. In Microbiology of Extreme Environments. Edwards, C. (ed.). New York: McGraw-Hill, pp. 52-92.

Krulwich, T.A. (2006) Alkaliphilic prokaryotes. Prokaryotes 2: 283-308.

Kulp, T.R., Han, S., Saltikov, C.W., Lanoil, B.D., Zargar, K., and Oremland, R.S. (2007) Effects of imposed salinity gradients on dissimilatory arsenate reduction, sulfate reduction, and other microbial processes in sediments from two California soda lakes. Appl Environ Microbiol 73: $5130-5137$.

Lane, D.J. (1991) 16S/23S rRNA sequencing. In Nucleic Acid Techniques in Bacterial Systematics. Stackebrandt, E., and

Goodfellow, M. (eds). Chichester, UK: John Wiley \& Sons, pp. 115-175.

Lefèvre, C.T., Abreu, F., Schmidt, M.L., Lins, U., Frankel, R.B., Hedlund, B.P., and Bazylinski, D.A. (2010) Moderately thermophilic magnetotactic bacteria from hot springs in Nevada. Appl Environ Microbiol 76: 3740-3743.

Lefèvre, C.T., Frankel, R.B., Abreu, F., Lins, U., and Bazylinski, D.A. (2011) Cultureindependent characterization of a novel, uncultivated magnetotactic member of the Nitrospirae phylum. Environ Microbiol 13: 538-549. 
McMillan, D.G.G., Velasquez, I., Nunn, B.L., Goodlett, D.R., Hunter, K.A., Lamont, I., et al. (2010) Acquisition of iron by alkaliphilic bacillus species. Appl Environ Microbiol 76: 69556961.

McNeill, D.F., Ginsburg, R.N., Chang, S.-B.R., and Kirschvink, J.L. (1988) Magnetostratigraphic dating of shallow-water carbonates from San Salvador, the Bahamas. Geology 16: 8-12.

Meyer, B., and Kuever, J. (2007) Phylogeny of the alpha and beta subunits of the dissimilatory adenosine-5'-phosphate (APS) reductase from sulfate-reducing prokaryotes - origin and evolution of the dissimilatory sulfate reduction pathway. Microbiology 153: 2026-2044.

Oremland, R.S., Dowdle, P.R., Hoeft, S., Sharp, J.O., Schaefer, J.K., Miller, L.G., et al. (2000) Bacterial dissimilatory reduction of arsenate and sulfate in meromictic Mono Lake, California. Geochim Cosmochim Acta 64: 3073- 3084.

Pikuta, E.V., Zhilina, T.N., Zavarzin, G.A., Kostrikina, N.A., Osipov, G.A., and Rainey, F.A. (1998) Desulfonatronum lacustre gen. nov., sp. nov.: a new alkaliphilic sulfate-reducing bacterium utilizing ethanol. Microbiology 67: 105-113.

Pikuta, E.V., Hoover, R.B., Bej, A.K., Marsic, D., Whitman, W.B., Cleland, D., and Krader, P. (2003) Desulfonatronum thiodismutans sp. nov., a novel alkaliphilic, sulfate-reducing bacterium capable of lithoautotrophic growth. Int J Syst Evol Microbiol 53: 1327-1332.

Pósfai, M., Moskowitz, B.M., Arató, B., Schüler, D., Flies, C., Bazylinski, D.A., and Frankel, R.B. (2006) Properties of intracellular magnetite crystals produced by Desulfovibrio magneticus strain RS-1. Earth Planet Sci Lett 249: 444- 455.

Postgate, J.R. (1963) Versatile medium for the enumeration of sulfate-reducing bacteria. Appl Microbiol 11: 265- 267. 
Saitou, N., and Nei, M. (1987) The neighbor-joining method: a new method for reconstructing phylogenetic trees. Mol Biol Evol 4: 406-425.

Sakaguchi, T., Burgess, J.G., and Matsunaga, T. (1993) Magnetite formation by a sulfate reducing bacterium. Nature 365: 47-49.

Sakaguchi, T., Arakaki, A., and Matsunaga, T. (2002) Desulfovibrio magneticus sp. nov., a novel sulfate-reducing bacterium that produces intracellular single-domainsized magnetite particles. Int J Syst Evol Microbiol 52: 215-221.

Sakai, S., and Jige, M. (2007) Characterization of magnetic particles and magnetostratigraphic dating of shallow-water carbonates in the Ryukyu Islands, northwestern Pacific. Island Arc 15: 468-475.

Schübbe, S., Kube, M., Scheffel, A., Wawer, C., Heyen, U., Meyerdierks, A., et al. (2003) Characterization of a spontaneous nonmagnetic mutant of Magnetospirillum gryphiswaldense reveals a large deletion comprising a putative magnetosome island. J Bacteriol 185: 57795790.

Schüler, D. (2002) The biomineralization of magnetosomes in Magnetospirillum gryphiswaldense. Int Microbiol 5: 209-214.

Schüler, D. (2008) Genetics and cell biology of magnetosome formation in magnetotactic bacteria. FEMS Microbiol Rev 32: 654-672.

Tamura, K., Dudley, J., Nei, M., and Kumar, S. (2007) MEGA4: molecular evolutionary genetics analysis (MEGA) software version 4.0. Mol Biol Evol 24: 1596-1599.

Thomas-Keprta, K.L., Clemett, S.J., Bazylinski, D.A., Kirschvink, J.L., McKay, D.S., Wentworth, S.J., et al. (2002) Magnetofossils from ancient Mars: a robust biosignature in the Martian meteorite ALH84001. Appl Environ Microbiol 68: 3663-3672. 
Wagner, M., Roger, A.J., Flax, J.L., Brusseau, G.A., and Stahl, D.A. (1998) Phylogeny of dissimilatory sulfite reductases supports an early origin of sulfate respiration. $J$ Bacteriol 180: $2975-2982$.

Weimeyer, S. (2005) Metals and trace elements in water, sediment, and vegetation at Ash Meadows National Wildlife Refuge-1993. Report by the United States Fish and Wildlife Service, Nevada Field Station.

Wolfe, R.S., Thauer, R.K., and Pfennig, N.A. (1987) A ‘capillary racetrack’ method for isolation of magnetotactic bacteria. FEMS Microbiol Ecol45: 31-35.

Wolin, E.A., Wolin, M.J., and Wolfe, R.S. (1963) Formation of methane by bacterial extracts. $J$ Biol Chem 238: 2882- 2886.

Zhilina, T.N., Zavarzin, G.A., Rainey, F.A., Pikuta, E.N., Osipov, G.A., and Kostrikina, N.A. (1997) Desulfonatronovibrio hydrogenovorans gen. nov., sp. nov., an alkaliphilic sulfatereducing bacterium. Int J Syst Bacteriol 47: 144-149. 

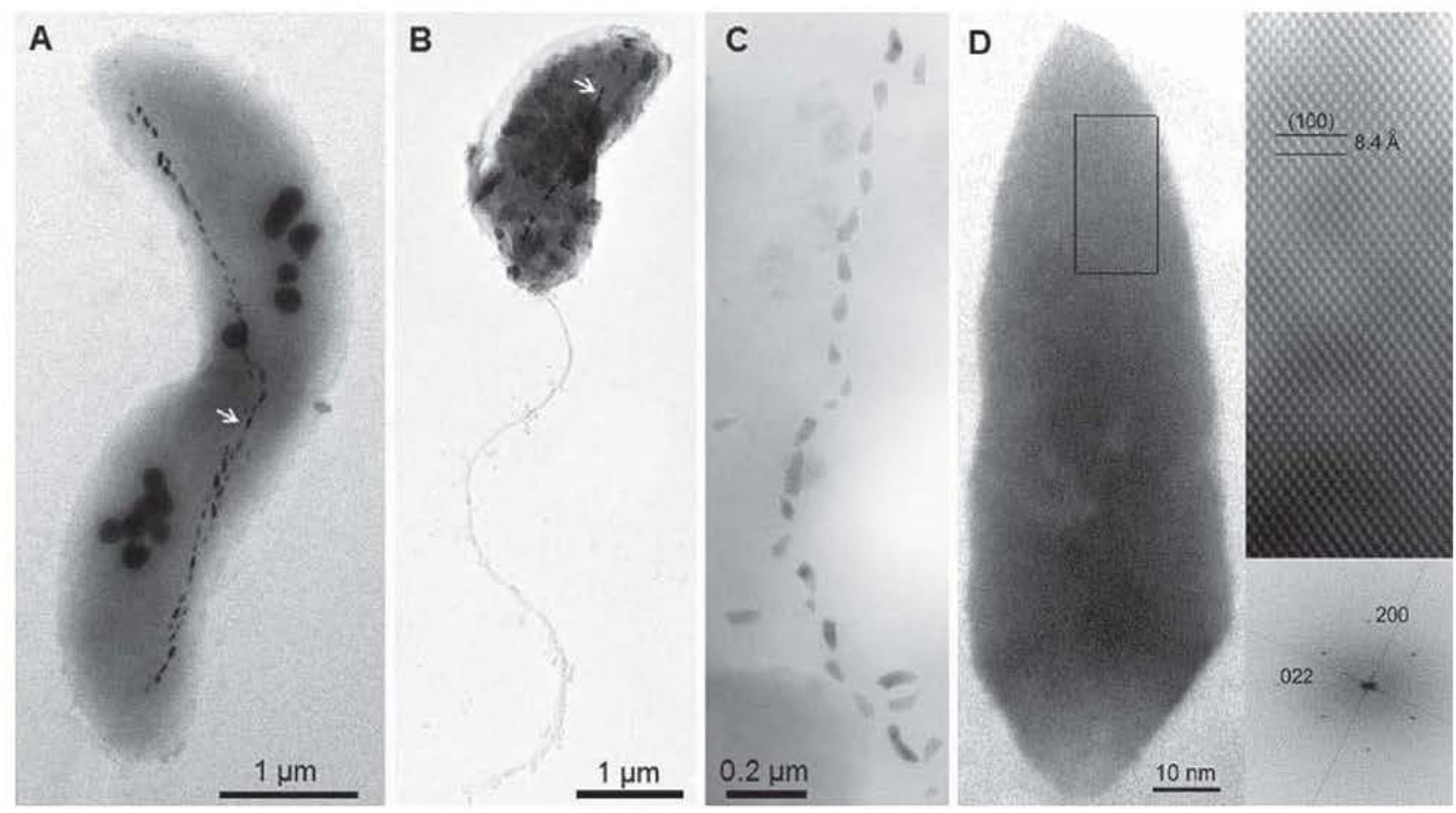

Fig. 1. Transmission electron microscope (TEM) images of alkaliphilic magnetotactic bacteria. A. An unstained magnetically purified cell from a brackish pool at Death Valley Junction.

B. A stained ( $1 \%$ uranyl acetate) cell grown in axenic culture from the hypersaline Mono Lake, California.

C. Bullet-shaped magnetosome chain of strain ZZ-1 grown in anaerobic medium with a high iron concentration $(200 \mu \mathrm{M})$.

D. High-resolution TEM image of a bullet-shaped crystal in a cell of strain AV-1 identified as magnetite on the basis of its lattice spacings and consistent with the Fourier transform of the image in the lower right inset, indexed according to the magnetite structure as viewed along [0 1 -1]. The inset in the upper right is a Fourier-filtered, enlarged image of the boxed area in the main panel.

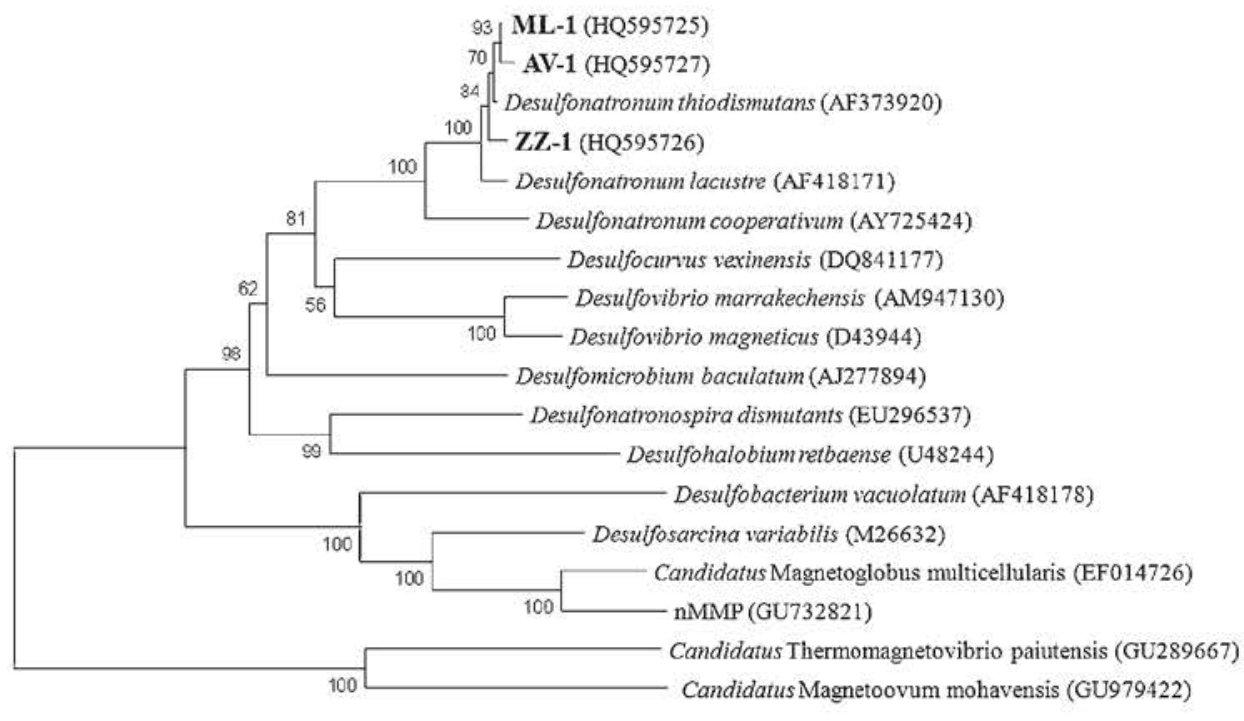

Fig. 2. Phylogenetic tree based on $16 \mathrm{~S}$ rRNA gene sequences, constructed using neighbour-joining analysis, showing the phylogenetic position of the alkaliphilic magnetotactic strains ML-1, ZZ-1 and AV-1 in the Deltaproteobacteria class. Bootstrap values at nodes are percentages of 1000 replicates. The magnetotactic bacteria Candidatus Thermomagnetovibrio paiutensis (Lefèvre et al., 2010) and Candidatus Magnetoovum mohavensis (Lefèvre et al., 2011) were used to root the tree (Nitrospirae phylum). GenBank accession numbers are given in parentheses. Bar represents $2 \%$ sequence divergence. 

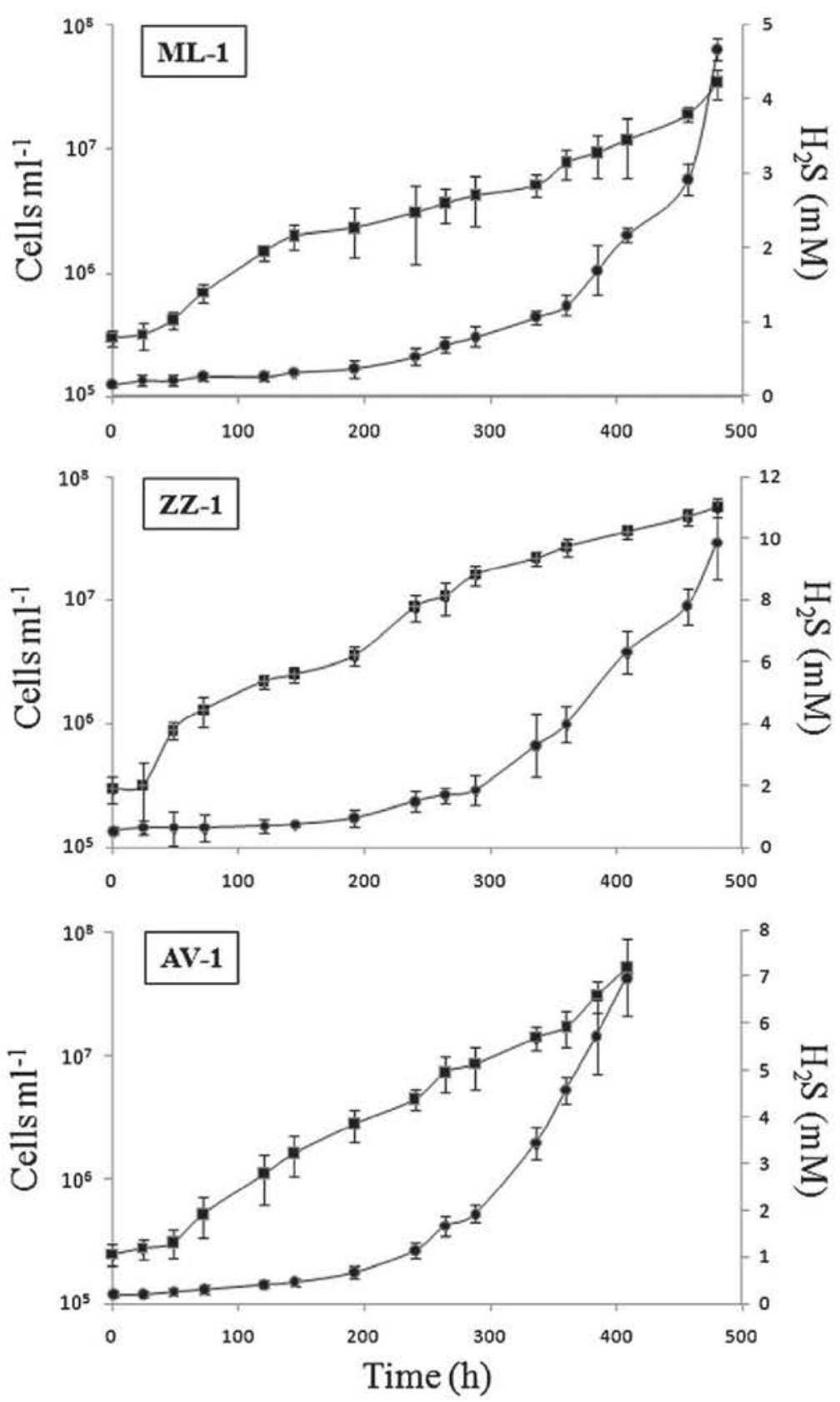

Fig. 3. Growth (n) and sulfide (I) production from sulfate in liquid cultures of the alkaliphilic magnetotactic strains $M L-1, Z Z-1$ and $A V-1$ grown anaerobically with formate as electron donor. 